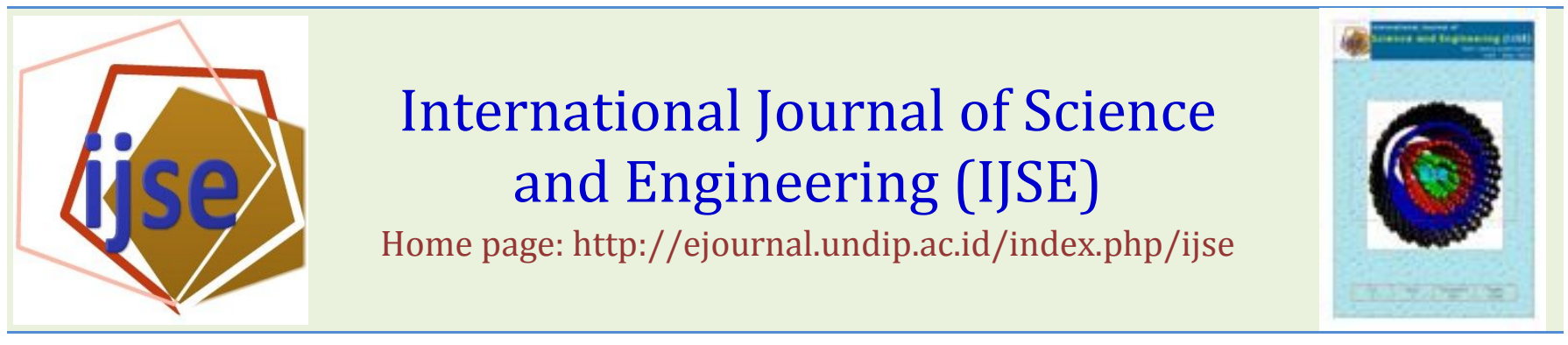

\title{
The Determinant Factors of Creative Economy Craftsmen Sustainability in South Sulawesi Province
}

\author{
Helda Ibrahim¹, Siti Amanah², Pang. S. Asngari², Ninuk Purnaningsih² \\ Email: heldaibrahim_uimeyahoo.co.id \\ ${ }^{1}$ Agribusiness Department Faculty of Agriculture, Makassar Islamic University \\ Tamalanrea Campus Jl. Perintis Kemerdekaan Km 9 No. 29 Makassar 90245 \\ ${ }^{2}$ Department of Society's Communication and Development \\ Faculty of Human Ecology, Bogor Agricultural University \\ IPB Campus Dramaga Bogor
}

\begin{abstract}
Creative economy craftsmen have big contribution to regional income and able to sustain in crisis. It can be seen on the average of Gross Domestic Product has employed 5.4 million in average for 2002-2009 with participation level of 5.8\%. Therefore, a strategic sustainability is needed especially for the determinant factors of sustainability related to creative economy craftsmen. This research aims to observe the determinant factors of sustainability of creative economy craftsmen in Wajo and Bulukumba Regencies in South Sulawesi Province. Sample for the research was 215 creative economy craftsmen. Data collection is conducted on January to April 2012 consists of primary and secondary data. Research method was using prospective analysis to determine important factors to the sustainability of creative economy craftsmen that predict future alternatives. Result from Rap-UEK simulation for the composite of five dimensions showed a less sustainable status of $48.97 \%$. Research results showed that there are six dominant or main factors in determining business sustainability of creative economy craftsmen, one place sale, coordination with the government and private sectors, capital source, increase in the product of creative economy business, business field and product development.
\end{abstract}

Keywords : determinant factors; business sustainability; creative economy craftsmen

Submission: August 14, 2013

Corrected : September 5, 2013

Accepted: September 11, 2013

Doi: 10.12777 /ijse.5.2.18-24

[How to cite this article: Ibrahim, H., Amanah, S., Asngari, P.S., and Purnaningsih, N. (2013). The Determinant Factors of Creative Economy Craftsmen Sustainability in South Sulawesi Province. International Journal of Science and Engineering, 5(2),18-24. Doi: 10.12777/ijse.5.2.1824]

\section{INTRODUCTION}

Handicraft product is a cultural expression that able to increase income and job opportunity in the sector. Handicraft has been part of an organized system transforming traditional handicraft to fulfill global market requirement due to economic act relationship (Granovetter, 1985, 1992; Biggart, 2002 ; Kahdar, 2009).

Silk is one of Indonesian cultures. Silk is generated from generations and in addition to its function for weaving practice, it contains educational meaning on the combination of color and motive displayed by creative economy craftsmen. This business of creative economy craftsmen is a hereditary business and a culture of Bugis society and is continually preserved because craftsmen of silk handicraft have been continually maintain this culture and pass their skill and expertise to their generations who will also maintain and preserve it. It is in accordance with researches from Sitorus (1999); Nawawi (2002), Yukimatsu, et al. (2008); Kahdar (2009); Idris (2009); Fitria (2011) that weaving activity continually adapts to condition in certain period.

The importance of small business role in developing national economy is indicated by the enactment of an Act of Republic of Indonesia No. 20, 2008 on small business and followed with governmental regulation of Republic of Indonesia No. 32, 1998 on the cultivation and development of small business. These rules are pointing on the recognition and effort to empower small business. As indicated in the governmental regulation that "small business is an integral part of national economy and it has strategic and important position, potential and roles in achieving strong national economic development, small business need to be empowered to be a strong and independent business and develop into medium business." 
Silk, as one of cultural heritages from the ancestors, is one of handicrafts need to be developed in South Sulawesi Province. Silk is born as an art contains a philosophy of the meaning of life from Bugis tribe's and Makasar culture. Therefore, the development of silk handicraft business will need creativity and innovation. These creativity and innovation continue to be developed by silk craftsmen. This is in accordance with Fitria (2011) that every region has its own design and motive based on their creativity. Problem in this research is based on obligation to preserve national cultural heritages and the awareness to participate in developing a better life for creative economy craftsmen of silk handicraft. Therefore, sustainability determinant factors to develop business potential of creative economy craftsmen need to be determined.

Wajo and Bulukumba Regencies are regencies with weaving handicraft industry-based cultural tourism. The industry itself is a service industry based on the people's economy that mostly based on the quality of human resources managing it; therefore, silk handicraft managed by craftsmen in those two regencies mostly are informal industry (household industry) and in small/micro scale. Based on the above background and problem, the research aims to analyze determinant factors of business sustainability of creative economy craftsmen in Wajo and Bulukumba Regencies of South Sulawesi Province.

\section{MATERIALS AND METHODS}

The research was conducted for three months from January to March 2012 at Wajo and Bulukumba Regencies.

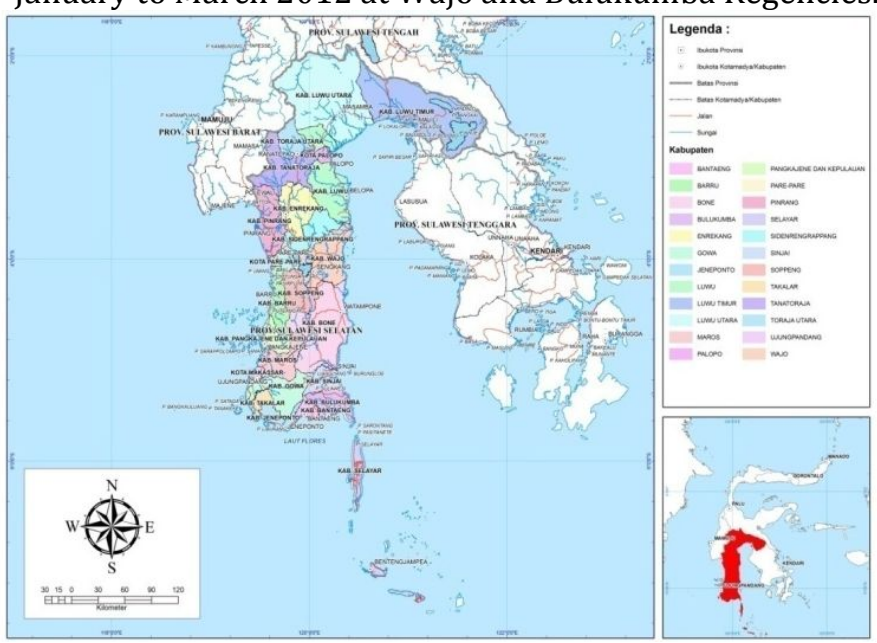

Fig. 1 South Sulawesi Map

\section{A. Research Method}

30 respondents were participated for the research who came from experts and has been selected purposively (purposive sampling) consisting of 15 people from Wajo Regency and 15 people from Bulukumba (Singaribum, 1989). The respondents were people from Forestry and Plantation Agency, Tourism and Creative Economy Agency, Dekranasda, Regional Government of Level II, and Agricultural Extension Worker of Wajo and Bulukumba Regencies, and society's figures, NGO, facilitator, cooperation, financial institutions, research and development institutions, limited company and exporter, and youth figures.

The research used prospective analysis to determine important factors in business sustainability of creative economy craftsmen of silk handicraft. Prospective analysis predicts alternatives happening in the future, either positive (desirable) or negative (undesirable). The analysis is used for: (1) preparing strategic acts needed and (2) observing the need for change in the future (Bourgoise, 2007; Budhidharsono, 2008).

From perspective analysis of informants, key factors for business sustainability of creative economy craftsmen of silk handicraft are known based on stakeholders' perspective. According to Hardjomidjojo (2004), stages in prospective analysis are:

1. Definition of the purpose of the system examined. The purpose of the system examined need to be specific and understandable by all experts whom going to be asked for their opinion; so that the experts will understand the scope and the study to bring common view on the system examined.

2. Identify factors influencing the achievement of the purpose, usually the need of the system's stakeholders. Based on the study purpose, experts are asked to identify factors influencing the achievement of the purpose. Experts are expected to represent the system's stakeholders so that the interest of all system's elements can be represented. In this stage, the definition of every factor should be clear and specific. Integration of experts' opinion can be done by taking modus value.

3. Asses the direct influence among factors. All factors identified will be assessed on the direct influence among them, as presented in Table 1

Table 1. Guidance to Assess Prospective Value

\begin{tabular}{cl}
\hline Score & Description \\
\hline 0 & No influence \\
1 & Small influence \\
2 & Medium influence \\
3 & Strong influence \\
\hline Source: Bourgeois (2007) &
\end{tabular}

Prospective analysis was used to identify dominant (key) factors influencing business sustainability of creative economy craftsmen of silk handicraft. The analysis was conducted on three stages:

a. Analyze the dominant and leverage variables obtained from sustainability status analysis

b. Analyze dominant variables and the need of representative respondents

c. Analyze composite variables in the first or second quadrant from prospective analysis in point $a$ and $b$, variables resulting from the first and second quadrants will be used in the analysis.

Matrix showed in Table 2 was used to see the direct influence among factors in the system conducted in the first stage of prospective analysis. 
Table 2. Direct influence among factors

\begin{tabular}{ccccccccc}
\hline \multirow{2}{*}{ From/toward } & \multicolumn{7}{c}{ Factors } \\
\cline { 2 - 8 } & A & B & C & D & E & F & G & H \\
\hline A & & & & & & & & \\
B & & & & & & & & \\
C & & & & & & & & \\
D & & & & & & & & \\
E & & & & & & & & \\
F & & & & & & & & \\
G & & & & & & & & \\
H & & & & & & & & \\
\hline
\end{tabular}

Source: Bourgeois (2007)

Note: A-H = important factors in the system

Scoring $0=$ No Influence

1 = Small Influence

2 = Medium Influence

4 = Strong Influence

The mechanism to fill the table is by giving a score of 3 if the direct influence among factors is very strong; 2 if the direct influence is medium; 1 if the direct influence is small and 0 if no influence among factors. After the key factors are obtained from Table 4.2, the next step is conducting matrix analysis of influence and dependency to find out the position of every factor in the empowerment of creative economy craftsmen of silk handicraft. In this step, prospective analysis was used as displayed in Fig. 2.

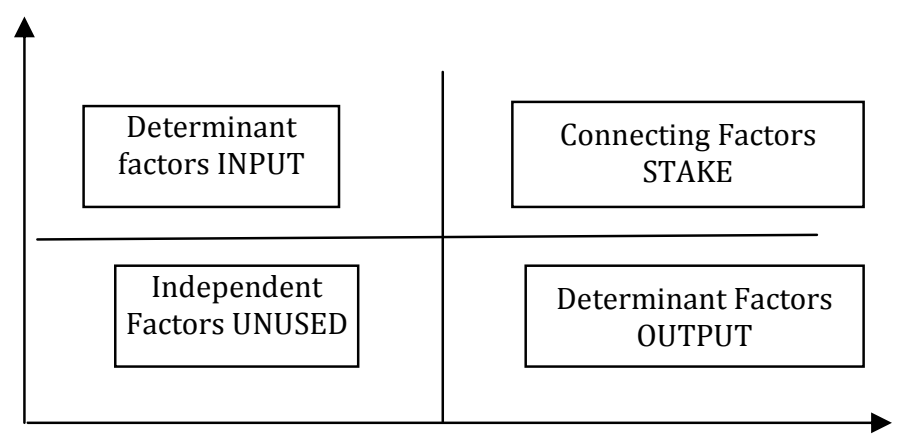

Fig 2 . The determination of influence and independency levels among business sustainability factors

Each quadrant in the diagram has its own factor characteristic; therefore, the followings are to obtain strategic scenario (Bourgeois and Jesis, 2004):

a. The first quadrant of determinant or driving variables consists of factors having strong influence with less strong dependency. This quadrant factor is the determinant or driving factors within category of the strongest factors in the examined system.

b. The second quadrant of connecting factors (leverage variables) shows factors with strong influence and dependency among factors. Factors within this quadrant are considered as the strong factor or variable.

c. The third quadrant of dependent factors (output variables) represents output factor with small influence but high dependency. d. The fourth quadrant of independent factors (margin variable) is marginal factor with small influence and low dependency level; therefore, these factors are independent in nature within the system.

Moreover, Bourgeois (2007) states that there are two types of variable spread in an influence and independency graph:

a. The spread tends to accumulate on the diagonal of fourth quadrant to second quadrant. This type shows unstable system built since most variables resulted are within marginal or leverage variables. It will be difficult to build strategic scenario for the future with this type of spread.

b. The spread accumulate in the first quadrant to the third as an indication of stable system built because it is shows strong relationship where the leverage variables strongly arrange the output variables. In addition, it is easier and more efficient to build strategic scenario with this type of spread.

\section{B. Types and Sources of Data}

The research used primary and secondary data. depth interview, questionnaire, observation and FGD. Secondary data is data collecting from the related institutions.

\section{RESULT AND DISCUSSION}

\section{A. Sustainability Index}

Research result shows that Rap-UEK simulation result indicates a less sustainable status of $48.97 \%$. Leverage factors need to be considered based on the leverage analysis results are: based on business sustainability analysis of creative economy craftsmen, attributes influencing the value of sustainability index on economic dimension that now became the leverage factors are: one place sale, less product development activities and less promotion on UEK (creative economy business) products. Regarding environmental dimensions, the leverage factors are knowledge on the impact of coloration, the impact of raw material supply, lack of training related to environment and less knowledge on environmental preservation. On social dimension, the leverage factors are the business is a hereditary business, lack of socialization from the government, lack of training from the government, and lack of training from the organization. For institutional dimension, the most influential factors are: pricing at the institution, no rules of play prevailed in the social institutions, and vertical relationship. Whereas on entrepreneurship actor dimension the influencing factors are understanding how to work on the opportunity of UEK, understanding how to make new motive for silk, and identify UEK thoroughly.

Strategy formulation for business sustainability of creative economy craftsmen is conducted using prospective analysis. Prospective analysis is used to gain sustainability scenario of creative economy craftsmen for the future. Some stages are required to obtain key factors in the formulation of a model: 
1. determining key factors gained from attributes influencing the index of business sustainability of creative economy craftsmen

2. identifying future key factors gained from the analysis

3. need analysis from every stakeholders; and

4. combining first and second stages to gain composite key factors between existing condition and need analysis

Those leverage factors were analyzed to determine key factors influencing strategy of business sustainability of creative economy craftsmen of silk handicraft. Result from prospective analysis, the determinant factors of business sustainability of creative economy craftsmen of silk handicraft is displayed in Figure 3.

Result from prospective analysis indicates that from 17 influencing attributes, 10 key factors were obtained (Fig. $3)$ : capital source, one place sale, home telephone, product of creative economy business, product development, rules of play at the institution, pricing at the institution, training from government, socialization by government and vertical relationship.

Based on Figure 3 each quadrant in the diagram has different factor characteristic: for the first quadrant, the determinant factors have the following attributes: capital source, one place sale, home telephone, and UEK product, which has strong influence but less dependency. Factors in this quadrant are determinant or leverage factors within strongest category in the examined system.

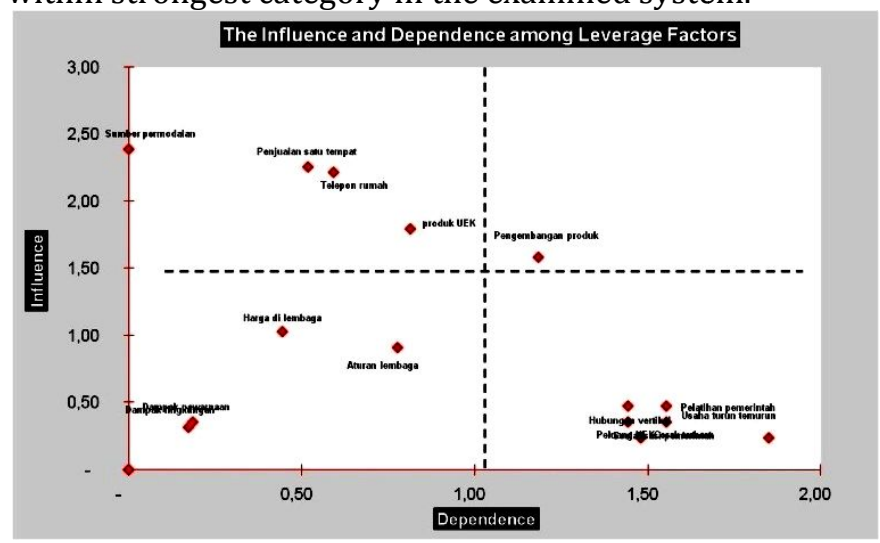

Fig. 3 The influence and dependency among leverage factors based on analysis of business sustainability of creative economy craftsmen

These determinant factors are the driving factors in conducting creative economy business but the dependency is not strong, for example, in case of capital source, when the craftsmen has no capital, they still have another alternative by borrowing capital from broker or trader who often buy their product. Another case is for attribute of one place sale, in which traders or businessmen usually directly come to the craftsmen that makes dependency on one place. The craftsmen were less utilizing home telephone but mostly they use mobile phone for product marketing. Creative economy business do not depend on the quality product but on product order; therefore, the product will be produced depend on consumers' order, if the consumers want low price, they will use less quality of raw material but still in accordance with consumers' requirement.
In the second quadrant the connecting factor is product development. This factor indicates strong influence and dependency among factors. Factors within this quadrant are considered as strong factors or variables. The third quadrant is dependent factors, which are: lack of training from government, the business is a hereditary business, lack of socialization from government, lack of development on new motive on silk and lack of vertical relationship (cooperation) that can represent output factors in which the influence is small but high dependency. The fourth quadrant is independent factors (marginal variables) with attributes: price at the institution, rules of play at the institutions, lack of knowledge on colorization, and lack of knowledge on environment. These factors are marginal factors with small influence and low dependency; therefore, these factors are free in nature within the system.

\section{B. Stakeholders' Needs}

Result from interview and field survey show that in determining future empowerment strategy some factors need to be considered: (1) job opportunity expansion, (2) increase in employment absorption, (3) coordination between governmental institutions and private sectors, (4) increase in export, (5) increase in income, (6) a conducive business climate, (7) increase in human resources quality (8) a better cooperation among businessmen, (9) the availability of capital, (10) a develop market and business, (11) debt interest in accordance with the market, (12) increase in the quality of technology, (13) appropriate price and (14) the existence of supporting institution.

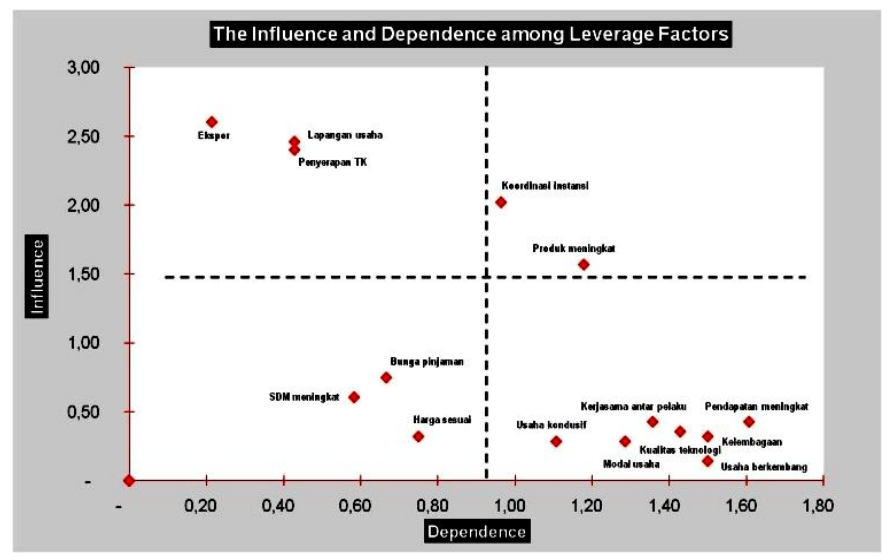

Fig. 4 The influence and dependency among leverage factors based on need analysis of stakeholder

Based on result in identifying the need of stakeholders, five key factors are obtained that become empowerment strategy. Result from prospective analysis shows that key factors need to be considered in the future (figure 4) are business field, increase in export, employment absorption, coordination with other institutions and increase in products.

\section{Key Factors of Empowerment Sustainability of Creative Economy Craftsmen}


Scenario for empowerment strategy of creative economy craftsmen is obtained based on key factors of sustainability resulting from Rap-UEK analysis describing existing condition and need analysis of stakeholder describing expected-future condition. Those key factors are obtained based on integration between sustainability analysis and need analysis of stakeholders.

The composite analysis based on interest level between sustainability analysis and need analysis resulted in key factors with high influence on system work, five key factors from sustainability analysis and five from need analysis of stakeholders. Factors or attributes from both analyses have similarities; therefore, those factors are combined to have ten key factors. Next, prospective analysis was conducted to obtain or determine the most dominant factor as indicated in Table 3.

Table 3 The combination of key factors having high influence

\begin{tabular}{cll}
\hline \multirow{2}{*}{ No } & \multicolumn{2}{c}{ Key Factors (Attributes) } \\
\cline { 2 - 3 } & Sustainability Analysis & \multicolumn{1}{c}{$\begin{array}{c}\text { Need Analysis of } \\
\text { Stakeholder }\end{array}$} \\
\hline 1 & Capital source & \\
2 & One place sale & \\
3 & Using home telephone & \\
4 & Increasing UEK product & \\
5 & Product development & \\
6 & & Business services \\
7 & & Increase in export \\
8 & & Employment absorption \\
9 & & Institutional coordination \\
10 & & Increase in UEK product \\
\hline
\end{tabular}

Composite analysis resulted in six dominant or main key factors, one place sale, institutional coordination, capital source, increasing the product of creative economy business, business field and product development. Figure 5 displays clearly on those key factors.

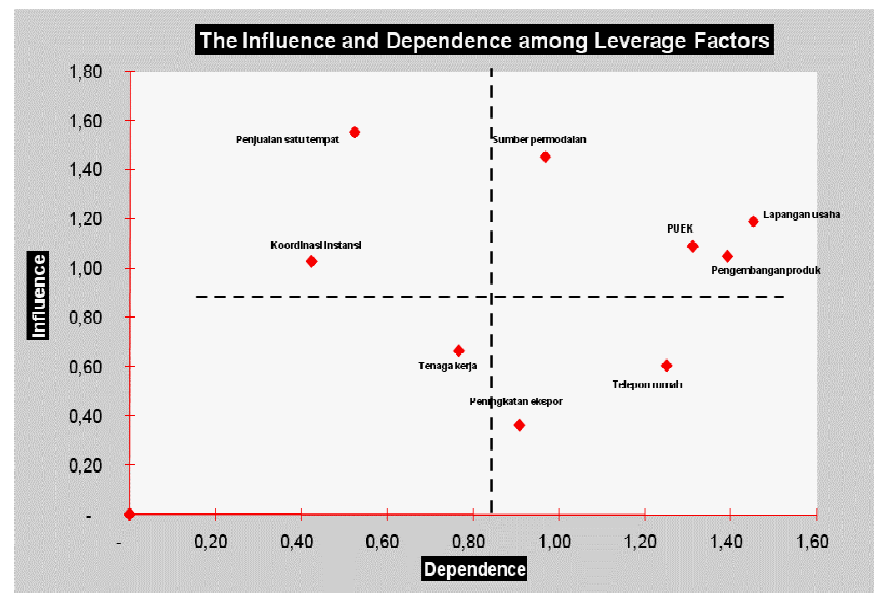

Fig. 5 The influence and dependency among leverage factors based on composite analysis of sustainability and stakeholder's need analyses.

Following are description on the situation of each dominant factor based on composite analysis' result between sustainability analysis (influence among factors) and need analysis (change expected):

\section{a. One Place Sale}

In average, creative economy craftsmen in both regencies sale their product in one place only due to unavailability of central market in their place; thus, these craftsmen bring their silk handicraft to the nearest central market. However, they prefer to have consumers to come to their place directly to buy their product. These craftsmen live in villages and transportation from the capital city of a regency to the villages is often difficult, especially in Bulukumba Regency. Hence, craftsmen are suggested to form a group to facilitate product marketing (Limostin, 2013).

Government needs to improve facilities and infrastructures, especially transportation to the capital city of a regency to facilitate silk handicraft marketing. One place sale is a determinant factor (first quadrant) in determining the success of empowering creative economy craftsmen and a factor with strong influence and less strong dependency.

Things need to be done in the future related to this selling activity are: (a) at present, one place sale is still conducted, (b) selling in other places at the regency, (c) selling in strategic places inside or outside regency or province.

\section{b. Coordination with Certain Institutions}

The coordination among institutions both government and private is not maximal. It can be seen from the lack of coordination between creative economy craftsmen and government and private sectors in term of program conducted by those two sectors. Based on Kuncoro' (2008) research, various partnership patterns between small and big businesses need to be developed. Craftsmen are unaware on training or internship conducted due to the lack coordination and there are no empowerment actors nor extension worker to help bridging the craftsmen with those sectors on the program.

Coordination with institutions is a determinant factor (first quadrant) in determining the success in empowering creative economy craftsmen. Therefore, coordination with government and private sectors through empowerment actors or extension worker needs to be done in order to inform creative economy craftsmen on programs conducted by those two sectors.

Things need to be done in order to improve the key factor of coordination with governmental and private institutions in the future are: (a) currently, coordination among institutions, both government and private is not clear, (b) coordination between governmental and private institutions is going pretty well (c) coordination between governmental and private institutions is going well and supported by the existence of clear duties and function for each institution.

\section{c. Capital source}

Some obstacles are found in the sustainability of creative economy business, one of the obstacles is capital source. The craftsmen weave based on wage; thus, they are known as wage worker because they do not have enough capital to carry out weaving activity due to expensive raw material. Therefore, they depend on businessmen who empower them. The weak capital access for craftsmen in financial institution (bank) due to the inexistence of craftsmen institution. Even if it does exist, it 
will be very weak, in which institutional group and composite group (gapoktan) or cooperation are not working as it is expected as the facilitator.

This factor is a connecting factor (second quadrant) and has strong influence and dependency among factors. In the future, things to be done to improve the key factors are: (a) now, craftsmen have no access to capital sources, (b) craftsmen have capital source access through financial institutions, (c) craftsmen have strong access and source to capital in financial institutions.

\section{d. Increase in the Product of Creative Economy Business}

Instead of depend on the product quality, product of creative economy depends on the product order; therefore, product is produced based on consumers' order if the consumers want low price product, the product will be produced using less quality raw material but still in accordance with consumers' requirement. However, in addition to produced based on consumer's order, craftsmen should maintain to produce quality products so their products can be exported.

Creative economy craftsmen are faced with high price on raw material. In their opinion, not all consumers are able to buy high quality product with high price; therefore they take order for law quality product using raw material from synthetic yarn with low price. In this case, consumers are able to choose whether to buy low or high quality products. It is in accordance with Lemhanas (2012) that collaboration between various actors, expert, business field and government, is needed to increase the development of creative economy products.

In the future, things need to be done are: (a) at present, raw material constrains the increase in product, (b) increase in raw material need to be supported by raw material supplier, (c) increase in raw material need to be supported by partnership program with raw material supplier.

\section{e. Product Development}

Creative economy craftsmen hope to be able to develop their product by not only weaving but also produce more creative product such as tie, wallet, lipstick case, pencil case, etc. However, this expectation is constrained with capital access even though they already empowered by the businessmen. It is in line with Yuli et al. (2006) stating that product diversification and business capital have helped the sustainability of a business that has been the obstacle.

In the future, things need to be done are: (a) at present, craftsmen have not yet conducted any product development, (b) developing product on their own business with sufficient capital access, (c) developing product on their own business with capital access in a partnership.

\section{f. Business Field}

The existence of a growing business field is important in the management of sustainability creative economy. Conflict of interest exists between businessmen and craftsmen. On one hand, craftsmen want to have new business field from their weaving activity such as producing traditional cake or rice cake. Whereas, on the other hand, businessmen do not think about business sustainability; they only care about the craftsmen to continue do their weaving activity with lower wage.

Craftsmen institution is one of ways to be conducted to anticipate the situation so that pricing for silk handicraft product produced by craftsmen is based on agreed rules at the institutions and access to capital in the institution will work as expected by craftsmen. Therefore, industrial sector development should be directed to the application of creative economy concept. Silk craftsmen empowerment should be followed with the development of creative economy concept by creating value added product and good marketing so that product will have more value. This is in accordance with Suandi et al. (2011) stating that natural resources and community's talent are opportunities to open new business field.

Things need to be done in the future to improve key factor of business field are: (a) at present, no business field expansion is conducted, (b) business field expansion is conducted through the support of craftsmen institution, (c) business field expansion is conducted through the support of craftsmen institution with creative economy concept and by building partnership relationship.

\section{CONCLUSION}

It can be concluded from the research result that there are six determinant factors for the sustainability of creative economy craftsmen, (1) one place sale, (2) institutional coordination, (3) capital source, (4) increasing the product of creative economy business, (5) business field, and (6) product development.

\section{REFERENCES}

Biggart, Nicole Woolsey, (2002). READINGS IN ECONOMIC SOCIOLOGY. Malden, Massachussetts, USA: Blackwell Publishers.

Bourgeois R and F Jesus. (2004). PARTICIPATORY PROSPECTIVE ANALYSIS, EXPLORING AND ANTICIPATING CHALLENGES WITH STAKEHOLDERS. Center for Alleviation of Poverty throught Secondary Crops Development in Asia and The Pacific and French Agricultural Research Centre for International Development.

Bourgeois R, (2007). PROSPECTIVE ANALYSIS. WORKSHOP MATERIAL TRAINING OF TRAINER ICASEPS. Bogor.

Budiharsono S, (2008). THE INCREASE ON FOOD SECURITY THROUGH LOCAL DEVELOPMENT. Bogor. Bappeda Kabupaten Bogor (Agency for Regional Development of Bogor Regency).

Fitria, Dwi, (2011). BETWEEN LOCAL WISDOM AND MODERNITY. National Journal;

doi:http://nasional.jurnas.com/halaman/8/2011-09-11/181757

Granovetter, M, (1985). ECONOMI ACTION AND SOCIAL STRUCTURE; THE PROBLEM OF EMBEDDEDNESS. American Journal of Sociology" Vol. 91, pp. 481-510

Granovetter, M., Sweddbera R., (1992). THE SOCIOLOGY OF ECONOMIC LIFE. Boulder, San Fransisco, Oxford: Westview Press.

Hardjomidjojo H. (2004). GUIDANCE ON WORKSHOP OF PROSPECTIVE ANALYSIS. Agricultural Industrial Technology Department. Faculty of Agricultural Technology. IPB, Bogor

Idris, Rabihatun, Hasnawi, Haris, and Suraidah H., (2009). THE COMBINATION OF TRADITIONAL WOVEN OF BUGIS-MALAYSIA (AN INVESTIGATION ON TRADITIONAL WOVEN BUGIS-MALAYSIA REFLECTING RELATIONS BETWEEN NATIONS). Research report. LPM-UNM (Makassar State University), Makassar.

Kuncora, Mudrajad, (2008). SMALL BUSINESS IN INDONESIA: PROFILE, PROBLEM AND EMPOWERMENT STRATEGY. EConomic Journal Volume 7 No 2 pp 1-10. 
Kahdar, Kahfiati, (2009). ESTHETIC ADAPTATION ON LIPPA BUGIS MOTIVE. Bandung. PPS -Institute of Technology Bandung. Dissertation.

Lembaga Ketahanan Nasional, (2012). THE DEVELOPMENT OF CREATIVE ECONOMY. Lemhanas (National Defense Institute) Journal of Study. Volume 14 December 2012. Jakarta.

Limostin, T, (2013). THE DEVELOPMENT OF LEATHER CRAFT AND THE INFLUENCE ON SOCIAL-ECONOMIC LIFE IN MAGETAN REGENCY. Journal Candi FKIP UNS Volume 5 No 1 : 1-10

Nawawi, Muhammad dan SP, Gustami, (2002). THE ART OF TRADITIONAL SILK WOVEN CRAFT OF BUGIS WAJO, SOUTH SULAWESI, CHALLENGE AND HOPE. Journal Sosiohumanika (15) 1 : 1-14, January 2002. Yogyakarta: Faculty of Letters-UGM.

Singarimbun, $\mathrm{M}$ and S. Effendy. (1989). SURVEY RESEARCH METHODOLOGY. Jakarta.
Sitorus, MT, Felix, (1999). THE FORMATION OF LOCAL ENTREPRENEUR IN INDONESIA; WEAVING ENTREPRENEURS IN BATAK TOBA COMMUNITY. Dissertation in SPS-IPB. Bogor; Bogor Agricultural University.

Suandi Edi Hamid dan Y.Sri Susilo, (2011). DEVELOPMENT STRATEGY OF SMALL, MICRO AND MEDIUM BUSINESS IN SPECIAL DISTRICT YOGYAKARTA PROVINCE. Development Economy Journal Volume 12 Nomor 1 Juni 2011 pp 45-55.

Yuli Sri, Enny Zuhny K., Nanie Asri Y., (2006). DESIGN DEVELOPMENT OF TEXTILE CRAFT PRODUCT IN CONVECTION BUSINESS. Journal Yogyakarta State University. Volume 201 : 10.

Yukimatsu, Keiko, Chantachon, Songkoon, Pothisane, Souneth Kobsiripha, Wissanu. (2008). THE ADDED VALUES OF LOCAL SILK TEXTILE; THAI-LAO MATMILL AND JAPANESE TUMUGI KATSURI, SOJOURN. Journal of Social Issues in Southeast. Asia Volume 23 Number 2, October 2008, pp 234-251. 